\title{
EFFICACY OF BRAIN GYM ON THE COGNITIVE FUNCTION IMPROVEMENT OF PEOPLE WITH DEMENTIA
}

\author{
Fery Agusman Motuho Mendrofa ${ }^{{ }^{*}}$, Dwi Indah Iswanti ${ }^{2}$ Umi Hani $^{1}$ \\ ${ }^{1}$ Departement of Community Health Nursing, STIKes Karya Husada Semarang, Jl. R. Soekanto No.46, Sambiroto, \\ Kec. Tembalang, Kota Semarang, Jawa Tengah, Indonesia 50276 \\ ${ }^{2}$ Departement of Mental Health Nursing, STIKes Karya Husada Semarang, J1. R. Soekanto No.46, Sambiroto, Kec. \\ Tembalang, Kota Semarang, Jawa Tengah, Indonesia 50276 \\ *ferysinga@gmail.com
}

\begin{abstract}
Dementia is a neurodegenerative syndrome caused by a chronic and progressive disorder accompanied by decreased brain function that affects emotions, memory, decision making, behavior and other brain functions that interfere with daily activities. This study aimed to determine differences in cognitive function in elderly dementia before and after brain exercise. This was a quasi-experimental research with one group pre and post-test design conducted in June 2020. The population was residents in some nursing homes in Semarang City. Samples who were willing to participate in research, 60-80 years old, and had Clock Drawing Test score in more than 2 were included for this study. The sample in this study was 63 older adults who were selected using a purposive sampling technique. The respondents enrolled in brain gym eight times each morning for 10-15 minutes in 2 weeks. Due to the pandemic, these interventions assisted by facilitators and adhered to health protocols in every interaction. The cognitive function obtained from the Short Portable Mental Status Questionnaire for pre and post-test. Univariate analysis described cognitive function in the elderly before and after brain exercise. The normality test using Shapiro Wilk showed that the data were normally distributed so that the dependent T-test was carried out to determine the effectiveness of brain exercise therapy on cognitive function in elderly dementia. The mean cognitive function before brain exercise was 6.6, and after brain exercise, it was 8.8. There was a significant difference between cognitive function before and after brain exercise ( $\mathrm{p}$-value < 0.05 ). Brain exercise affects improving cognitive function in older adults with dementia.
\end{abstract}

Keywords: brain gym; cognitive; dementia

\section{INTRODUCTION}

Dementia is a neurodegenerative syndrome caused by a chronic and progressive disorder accompanied by decreased brain function that affects emotions, memory, decision making, behavior and other brain functions that interfere with daily activities (Mendrofa, Hani, Putri, et al., 2020). Dementia is often experienced by the elderly. Elderly is someone who is more than 60 years and over. The older adults will experience the aging process simultaneously with a process of decline. These physical condition make older adult in conditions of dependence on other people and can cause anxiety and depression. One of the body systems that experience decline is the cognitive or intellectual system (Dewi, 2016; Herawati, 2014). Cognitive is the process of identifying, selecting, interpreting, filtering and using information that makes sense. The cognitive function itself is a conscious mental activity such as thinking, remembering, learning and using language (Djajasaputra \& Halim, 2019).
Decreased cognitive function in the elderly, such as often forgetting about themselves, other people, times, places and daily activities, is often considered as a normal condition. This deterioration of cognitive function affects the quality of life in the elderly (Dewi, 2016). The deterioration of the process of remembering in the elderly occurs gradually. With changing health conditions, the elderly need to be aware that they must be aware of brain disorders that cause memory processing disorders. If there is a decrease in memory abilities, the elderly should be aware of the occurrence of dementia (Jing et al., 2016).

Today, 47 million people live with dementia worldwide, and it is projected to increase to more than 131 million by 2050 , as populations age (Prince et al., 2016). Indonesia is the world's fourth most populated country. Its large population (over 257 million people in 2015) is relatively young compared to other 
countries in South East Asia. However, even with the relatively low proportion of older people compared to other countries, Indonesia is still ranked eighth in the world in terms of the overall number of older people. There are no locally generated estimates of the prevalence of dementia in Indonesia so far. Using data from comparable countries, the World Alzheimer Report 2015 estimated that in 2015 there were just over 556,000 people with dementia in Indonesia. The prevalence of dementia increases by $1 \%$ at the age of 60 years and doubles every five years, reaching $30 \%-50 \%$ by the age of 85 years (Soni et al., 2014). Much of the increase will take place in low and middle-income countries $58 \%$ in 2015, rising to $63 \%$ in 2030 and $68 \%$ in 2050 . The prevalence of dementia in Indonesia reached 1.2 million cases in 2015 and will continue to increase to 4 million in 2050 (Alzheimer's Indonesia, 2019).

Based on a preliminary survey conducted by researchers in July 2019, 35 elderly people $(100 \%)$ were interviewed. It was found that 14 people $(40 \%)$ forgot about the activities they had done, 10 people $(28.5 \%)$ forgot their age, and 10 people $(28.5 \%)$ forgot to take their medication schedule. Brain gym exercise is one way to prevent and overcome cognitive dysfunction. Brain exercise aims to increase self-confidence, strengthen learning motivation, stimulate the left and right brain, relax the brain and can improve cognitive function (Suhari et al., 2019). Research also shows that the brain gym has an effect on cognitive function. The brain gym is a series of simple motion exercises and is an alternative therapy that aims to increase the flow of blood and oxygen to the brain and stimulate both parts of the brain to work. It can maintain an optimal balance between the right and left brain performance. The brain gym provides a repair stimulus to fibres in the corpus callosum that provide many two-way neural connections between the cortical areas of the two hemispheres of the brain, including the hippocampus and amygdala (Hukmiyah et al., 2019). This was a quantitative study aimed to analyze the effectiveness of brain gym on cognitive function in the elderly with dementia in Semarang.

\section{METHODS}

It was a quasi-experimental study used onegroup pre and post-test design. This study aimed to determine the effect of brain exercise on improving cognitive function in elderly dementia. This research was conducted at some nursing homes in Semarang in June 2020. Letters of invitation were sent out to nursing homes in Semarang City. A total of 74 residents were contacted for sample selection, and 63 of them agreed to participate. Each participant was informed about the study nature, purpose, and benefits, the right to refuse or withdraw at any time, as well as the obtained data confidentiality. The study was conducted with 55 respondents who met the inclusion criteria (Figure 1). Participants were selected based on inclusion criteria: (1)willing to participate in research, (2)60-80 years old, (3)Clock Drawing Test (CDT) score was more than 2. Respondents in temporary respite care, and those who were reported having negative behaviors were excluded as they were likely unable to follow the brain gym instruction were excluded from this study. The director of nursing home compiled a list of eligible residents based on the criteria.

Information on the capacity to give informed consent was also provided during this process. Once consent was obtained, the Short Portable Mental Status Questionnaire (SPMSQ) was conducted with a nursing staff who has experienced for 3 years who knew the participants well and has signed informed consent from the researcher. Demographic details were collected from the participant. The reasons for exclusion from this study were younger than 60 years or older than 80 years, did not have dementia symptoms from SPMSQ, having a diagnosis of major depression, and consuming medication that affected their activity.

The day before giving the first brain gym therapy, the respondents' cognitive function was observed by SPMSQ. Respondents were also explained about the brain gym activity using a brain gym guideline book. Brain gym was carried out eight times each morning for 10-15 minutes in 2 weeks of intervention. Due to the COVID-19 pandemic, the therapy was 
held in an open field in the nursing homes assisted by facilitators. The respondents, facilitators, and researchers also adhered to health protocols in every interaction. Respondents' cognitive function was then observed the day after this therapy for being post-test. Cognitive function before and after treatment was measured using the SPMSQ. Univariate analysis was performed to describe the cognitive function in the older adults before and after brain exercise, including the mean, maximum and minimum values. Bivariate analysis was used to determine the effectiveness of brain exercise therapy on cognitive function in elderly dementia. The data showed a normal distribution with the Shapiro Wilk normality test so that the bivariate analysis was carried out by using the dependent t-test. The study was declared to have passed the ethical review by the Research Ethics Committee Karya Husada Semarang College No.60/KH.KEPK/KT/IV/2020.

\section{RESULTS}

\section{Demographic Characteristic}

63 home care residents with dementia signs and symptoms were recruited to the study.
Demographic characteristics by age, sex, and clock drawing test are presented in Table 1 and 2. Results showed that mean of elderly in nursing homes in Semarang was 71 years old.

\section{Cognitive Function before and after Brain Gym Intervention}

The standard deviation, minimum, and a maximum score of cognitive function of dementia elderly increased after brain gym, shown in Table 3. Mean of cognitive increased from 6.6 before brain gym intervention to 8.8 after the intervention. Statistical analysis using the paired t-test indicated that there was a significant difference in cognitive function score prior and after brain gym therapy (Asymp. Sig 2 tailed <0.05) (Table 2). This showed that there was an effect of brain exercise on improving cognitive function in elderly dementia. Table 2 shows the standard deviation value of 0.78 , which means that most of the data in the collection is 0.78 from the average. And obtained a standard error value of 0.24 which means that it reflects the accuracy of the selected sample to the population.

Tabel 1.

Age Characteristic of Respondents $(n=63)$

\begin{tabular}{ccccc}
\hline & $\mathrm{n}$ & Mean & Min & Max \\
\hline Age & 63 & 71,00 & 64 & 88 \\
\hline
\end{tabular}

Table 2.

Respondents' Clock Drawing Test Score $(n=63)$

\begin{tabular}{cccccc}
\hline & & \multicolumn{4}{c}{ Clock Drawing Test Score } \\
\hline Sex & & $1-2$ & 3 & 4 & 5 \\
& Male & 0 & 40 & 0 & 0 \\
\multirow{2}{*}{ Age } & Female & 0 & 20 & 3 & 0 \\
& Pre Elderly & 0 & 25 & 0 & 0 \\
& Early Elderly & 0 & 35 & 0 & 0 \\
& Late Elderly & 0 & 0 & 3 & 0 \\
\hline
\end{tabular}

Table 3.

The Mean of Cognitive Function Ability of Dementia Elderly

\begin{tabular}{ccccc}
\hline Statistic & Minimum & Maximum & Mean & Deviation Standard \\
\hline Pre & 4 & 9 & 6,6 & 1,71 \\
\hline Post & 6 & 12 & 8,8 & 1,93 \\
\hline
\end{tabular}


Table 4.

Paired T-Test

\begin{tabular}{ccccc}
\hline Cognitive Function Score & Mean & SD & SE & P value \\
\hline Pre Test - Post Test & -2.2 & 0.78 & 0.24 & 0,001 \\
\hline
\end{tabular}

\section{DISCUSSION}

\section{Characteristic of People with Cognitive Impairment}

Older people related to aging process will experience a decline in cognitive and psychomotor functions. Cognitive functions include the process of learning, orientation, understanding, and attention cause the negative behavior of the elderly (Suhari et al., 2019). This recent study showed that 27 respondents were classified as having severe cognitive dysfunction (the correct answer of 1-6) and 28 were moderate cognitive function disorder (7-9 correct answers). The remembrance process in the elderly occurs gradually. With changing health conditions, the elderly need to be aware that they must be aware of brain disorders that cause memory processing disorders. It is necessary for the elderly to be aware of the occurrence of dementia since the older age means a higher risk of dementia (Mendrofa, Hani, Putri, et al., 2020).

The older age means a higher risk of dementia. Dementia mainly affects older people, although there is a growing awareness of cases that start before the age of 65 . Population aging is having a profound impact on the emergence of the global dementia epidemic. A negative effect of the rapid aging of the population is the increase in the number of people with dementia. Although dementia mainly affects older people, it is not a normal part of aging. According to different estimates, between $2 \%$ and $10 \%$ of all cases of dementia start before the age of 65 . The prevalence doubles with every five-year increment in age after 65 (Prince M, Wimo A, Guerchet M, 2015).

Decreased cognitive function may be related to the rarely used of the brain. Thus, maintaining the potential of the brain in aging process is critical. Older people need to keep learning and continuing to do some activities to stimulate the brain and improve human intelligence until of 80-90 years (Suhari et al., 2019).

\section{Effectiveness of Brain Gym Cognitive Function}

Cognitive training and physical exercise have been regarded as useful strategies to improve the cognitive function in older people even with cognitive impairment (Ball et al., 2002; Cancela et al., 2020). Brain exercise or brain gymnastics (brain gym) stimulate brain function to be more effective in the elderly and facilitate blood flow and oxygen to the brain. It is a series of simples movements that are fun to improve learning skills using the whole brain. The reason behind brain exercise was to prevent cognitive decline (Lowrani et al., 2020). Brain gym can raise awareness in the elderly.

Reticular activating system (RAS) that is an alertness center in human can be alerted again with brain gym. It provides a stimulus to repair the fibres in the corpus collosum which provides many two-way neural connections between the cortical areas of both brain hemispheres, including the hippocampus and amygdale. The hippocampus roles in consolidating as a cross-reference system and links certain aspects of memory stores in separate parts of the brain then increase nucleic acid in changes in neuronal memory. The brain gymnastic movement reactivates the neural connections between the body and the brain so as to facilitate the flow of electromagnetic energy throughout the body. This movement supports electrical and chemical changes that take place on all mental and physical events (Cancela et al., 2020; Suhari et al., 2019).

The recent study showed a difference in cognitive function after brain gym for two weeks. It proves that the brain gym has a positive impact on improving cognitive 
function in the elderly. Another study concluded that brain exercise affected on increasing the Mini-Mental State Examination (MMSE) score. Brain exercise in the elderly is expected to improve cognitive function that decreases in old age, as well as increase the enthusiasm and concentration of the elderly (Yusuf, A., Retno, I., \& Arifudin, D.J., 2016). It is in line with other studes that the brain gym has a significant effect on the improvement of cognitive function of the elderly (Amtonis \& Fata, 2014; Ardian \& Nuraini, 2018). Exercise in the brain gym stimulates the brain by releasing stress, increasing learning concentration, clearing the mind, improving memory and cognitive abilities such as alertness, concentration, and speed in the learning process (Azizah et al., 2017; Erwanto \& Kurniasih, 2018).

Brain gymnastics can activate three dimensions of the brain. The concentration dimension increases blood flow to the brain and increases oxygen reception. The lateral dimension stimulates the coordination of the two hemispheres of the left brain and right brain (improve breathing, stamina, release tension and reduce fatigue). The focusing dimensions that help release focus barriers from the brain (improve lack of attention and lack of concentration) (Suhari et al., 2019).

Many pieces of research have recommended that people who experienced declined cognitive function must make a top priority to improve their quality of life (Suhari et al., 2019). Brain gymnastic movements can improve intellectually including cross movements, with the hips, brain gymnastic movements that increase energy including gravity glide, relaxed hooks, earth buttons. Moderate-and vigorous-intensity leisure physical activity was associated with global cognitive function and specific cognitive domains, including memory (Ardian \& Nuraini, 2018; Engeroff et al., 2018).

Thus, brain gym could be a physical activity which is recommended to improve cognitive function. Brain gym is usually performed with music. The study examined the effects the music-with-movement intervention on the cognitive functions of people with moderate dementia stated that it improves the memory after six weeks of intervention. Music-withmovement intervention may be useful for enhancing the cognitive functions of people with dementia (Cheung et al., 2018).

Music can be a multisensory-stimulation environment as a therapy to prevent cognitive deterioration (Mendrofa, Hani, Iswanti, et al., 2020). Besides, regular exercise can increase a protein in the brain called Brain-Derived Neurotrophic Factor (BDNF). This BDNF protein plays an essential role in keeping nerve cells fit and healthy (Yuliati et al., 2018). Even though the proper procedures, a supportive research environment and good therapists also effect on the cognitive score improvement. Some older adults could not immediately pick up on the instructions, so instructors had to repeat the instructions given to the elderly several times.

\section{CONCLUSION}

Brain gym as a cognitive training and physical exercise have been regarded as useful strategies to improve the cognitive function in older people even with cognitive impairment. Exercise in the brain gym stimulates the brain by releasing stress, increasing learning concentration, clearing the mind, improving memory and cognitive abilities such as alertness, concentration, and speed in the learning process. Regular brain gym has a positive impact on improving cognitive function in the elderly. Brain gym stimulates brain function to be more effective in the elderly, and facilitate blood flow and oxygen to the brain.

\section{REFFERENCES}

Alzheimer's Indonesia. (2019). Statistics of Dementia. https://alzi.or.id/statistiktentang-demensia/

Amtonis, I., \& Fata, U. H. (2014). The Effect of Brain Gym to the Improvement of Cognitive Function. Jurnal Ners Dan Kebidanan (Journal of Ners and Midwifery), 1(2), 087-092. https://doi.org/10.26699/jnk.v1i2.art.p0 
87-092

Ardian, I., \& Nuraini, N. (2018). The Effectiveness of Brain Gym and Brain Vitalization Gym in Increasing Cognitive Function of The Elderly in Pucang Gading Social Rehabilitation Unit of Semarang. NurseLine Journal; Vol 3 No 1 (2018): Mei 2018DO 10.19184/Nlj.V3i1.7001.

https://jurnal.unej.ac.id/index.php/NLJ/a rticle/view/7001

Azizah, L., Martiana, T., \& Soedirham, O. (2017). The Improvement of Cognitive Function and Decrease the Level of Stress in the Elderly with Brain Gym. International Journal of Nursing And Midwifery Science (IJNMS), l(1 SEArticles).

https://doi.org/10.29082/IJNMS/2017/V ol1/Iss $1 / 33$

Ball, K., Berch, D. B., Helmers, K. F., Jobe, J. B., Leveck, M. D., Marsiske, M., Morris, J. N., Rebok, G. W., Smith, D. M., Tennstedt, S. L., Unverzagt, F. W., Willis, S. L., \& Group, for the A. S. (2002). Effects of Cognitive Training Interventions With Older AdultsA Randomized Controlled Trial. JAMA, 288(18), 2271-2281. https://doi.org/10.1001/jama.288.18.227 1

Cancela, J. M., Casal, Á., Sánchez-Lastra, M. A., \& Ayán, C. (2020). Brain Gym exercises versus standard exercises for institutionalised older people with cognitive impairment: a randomised controlled study. Asian Journal of Gerontology and Geriatrics, 15(1), 1-7. https://doi.org/10.12809/ajgg-2019-383oa

Cheung, D. S. K., Lai, C. K. Y., Wong, F. K. Y., \& Leung, M. C. P. (2018). The effects of the music-with-movement intervention on the cognitive functions of people with moderate dementia: a randomized controlled trial. Aging \& Mental Health, 22(3), 306-315. https://doi.org/10.1080/13607863.2016. 1251571

Dewi, S. R. (2016). Pengaruh Senam Otak Dan Bermain Puzzle terhadap Fungsi Kognitif Lansia di PLTU Jember. Jurnal Kesehatan Primer, $1(1$ SEArticles).

https://doi.org/10.5281/jkp.v1i1.69

Djajasaputra, A. D. R., \& Halim, M. S. (2019). Fungsi Kognitif Lansia yang Beraktivitas Kognitif secara Rutin dan Tidak Rutin. Jurnal Psikologi, 46(2), 85. https://doi.org/10.22146/jpsi.33192

Engeroff, T., Ingmann, T., \& Banzer, W. (2018). Physical Activity Throughout the Adult Life Span and DomainSpecific Cognitive Function in Old Age: A Systematic Review of CrossSectional and Longitudinal Data. Sports Medicine, 48(6), 1405-1436. https://doi.org/10.1007/s40279-0180920-6

Erwanto, R., \& Kurniasih, D. E. (2018). Perbedaan Efektifitas Art therapy dan Brain gym terhadap Fungsi Kognitif dan Intelektual pada Lansia Demensia di BPSTW Yogyakarta. Strada Jurnal Ilmiah Kesehatan, 7(2), 34-41. https://doi.org/10.30994/sjik.v7i2.165

Herawati, N. (2014). Pengaruh Senam Lansia Terhadap Tingkat Kecemasan Lansia Di Panti Sosial Tresna Werdha Sabai Nan Aluih Sicincin Kabupaten Padang Pariaman. Jurnal Keperawatan Jiwa ., Volume 2, 81-87. https://doi.org/https://doi.org/10.26714/j kj.2.2.2014.81-87

Hukmiyah, A. N., Bachtiar, F., Leksonowati, S. S., Keperawatan, F., Studi, P., Universitas, F., Fisioterapi, J., \& Kemenkes, P. (2019). Pemberian Brain Gym Exercise Dapat Meningkatkan Fungsi Kognitif Pada Lanjut Usia. Jurnal Vokasi Indonesia, 7(2), 11-18. https://doi.org/10.7454/jvi.v7i2.148 
Jing, W., Willis, R., \& Feng, Z. (2016). Factors influencing quality of life of elderly people with dementia and care implications: A systematic review. Archives of Gerontology and Geriatrics, $66,23-41$.

Lowrani, M., Indarwati, R., \& Lestari, P. (2020). Systematic Review Nonpharmacological Therapy for the Elderly to Prevent Dementia through Cognitive Stimulation Therapy: A Systematic Review. 15(2), 221-229. https://doi.org/http://dx.doi.org/10.2047 3/jn.v15i2.19018 This

Mendrofa, F. A. M., Hani, U., Iswanti, D. I., \& Semarang, K. H. (2020). Environmental Management to Control Behavioral and Emotional Problems in Elderly with Dementia. 0200(April), 9$21 . \quad$ https://he01.tcithaijo.org/index.php/ijphs/article/view/2 25812/164578

Mendrofa, F. A. M., Hani, U., Putri, A. A., \& Aeni, M. (2020). Natural light therapy to lower agitation and sleep disturbance of dementia patients in semarang. International Journal of Psychosocial Rehabilitation, 24(7), 7752-7759. https://doi.org/10.37200/IJPR/V24I7/PR 270746

Prince M, Wimo A, Guerchet M, A. D. I. (2015). World Alzheimer Report 2015: The Global Impact of Dementia | Alzheimer's Disease International. World Alzheimer Report 2013, 1-87.

Prince, M., Comas-Herrera, A., Knapp, M., Guerchet, M., \& Karagiannidou, M. (2016). World Alzheimer Report 2016 Improving healthcare for people living with dementia. Coverage, Quality and costs now and in the future. Alzheimer's Disease International (ADI), 1-140. https://www.alz.co.uk/research/worldreport-2016

Soni, S., Kumar, P., Verma, V. S., \& Sharma, M. (2014). Significance of Indian Medicinal Plants used for Treatment of
Dementia. Asian Journal of Research in Pharmaceutical Sciences, 4(4), 202205.

Suhari, Astuti, A., Rahmawati, P. M., \& Musviro. (2019). Brain Gym Improves Cognitive Function for Elderly with Dementia. Jurnal Ners, 5(031), 79-86. https://doi.org/10.5281/zenodo.3365503

Yuliati, Y., Hidaayah, N., \& Hidaayah, N. (2018). Pengaruh Senam Otak (Brain Gym) terhadap Fungsi Kognitif pada Lansia di RT 03 RW 01 Kelurahan Tandes Surabaya. Journal of Health Sciences, $\quad 10(1 \quad$ SE- $)$. https://doi.org/10.33086/jhs.v10i1.149 
Jurnal Keperawatan Jiwa Volume 8 No 4, November 2020, Hal 557 - 564

FIKKes Universitas Muhammadiyah Semarang bekerjasama dengan PPNI Jawa Tengah 